\title{
The lithium, boron and strontium isotopic systematics of groundwaters from an arid aquifer system: Implications for recharge and weathering processes
}

\author{
Karina Meredith $^{\mathrm{a}, *}$, Takuya Moriguti ${ }^{\mathrm{b}}$, Paul Tomascak ${ }^{\mathrm{c}}$, Suzanne Hollins ${ }^{\mathrm{a}}$, \\ Eizo Nakamura ${ }^{\mathrm{b}}$ \\ a Australian Nuclear Science and Technology Organisation, Institute for Environmental Research, Locked Bag 2001, \\ Kirrawee DC, NSW 2232, Australia \\ ${ }^{\mathrm{b}}$ The Pheasant Memorial Laboratory (PML) for Geochemistry and Cosmochemistry, \\ Institute for Study of the Earth's Interior, Okayama University at Misasa, Tottori 682-01, Japan \\ ${ }^{\mathrm{c}}$ State University of New York at Oswego, Oswego, NY 13126-3599, USA
}

Received 1 May 2012; accepted in revised form 16 February 2013; available online 27 February 2013

\begin{abstract}
Saline groundwaters are common to inland Australia, but their hydrochemical evolution and origin remain largely unknown. The saline groundwaters in the alluvial aquifers of the Darling River have previously been found to exhibit broad similarity in traditional hydrochemical and isotopic tracers. By contrast, in this study the trace element isotopes $\left(\delta^{7} \mathrm{Li}, \delta^{11} \mathrm{~B}\right.$ and ${ }^{87} \mathrm{Sr} /{ }^{86} \mathrm{Sr}$ ) have illuminated more complex hydrogeochemical processes in the same aquifer system. This paper reports the first ever set of $\delta^{7} \mathrm{Li}$ values in any groundwater system in Australia. They varied from +5.8 to +16.2 with an average value of $+9.7 \%(n=19)$ in the alluvial aquifers of the Darling River catchment. The $\delta^{11} \mathrm{~B}$ values were all higher than seawater and close to some of the highest $\delta^{11} \mathrm{~B}$ values ever reported in the literature for a groundwater system $(+44.4$ to +53.9 ; average: $+48.8, n=17)$. The ${ }^{87} \mathrm{Sr} /{ }^{86} \mathrm{Sr}$ ratios ranged from 0.708 to 0.713 , with an average value of $0.709(n=19)$. The differing signatures in these trace element isotope values, highlighted by discovery of the deeper older groundwater system with heavier Li isotope values and higher ${ }^{87} \mathrm{Sr} /{ }^{86} \mathrm{Sr}$, is an important finding of this research. Simple mixing models between river water and saline groundwater cannot explain the observed variation in trace element isotopes. Hydrochemical evolution was found to be dependent on proximity to the Darling River and depth. Varying degrees of $\mathrm{Li}$ and B isotopic fractionation during watersediment interaction were interpreted to account for the evolution of the saline groundwaters. The measurement of these trace element isotopes has permitted delineation of groundwater end-members that would have otherwise not been identified; in their absence an inaccurate interpretation of the hydrochemical evolution of these saline groundwaters would have been made. This study highlights the importance of a multi-tracer approach, which includes trace element isotopes, in resolving complex geochemical processes in groundwater in semi-arid to arid zone environments.
\end{abstract}

Crown copyright (C) 2013 Published by Elsevier Ltd. All rights reserved.

\section{INTRODUCTION}

Saline groundwaters, such as those found in the Darling River catchment $\left(650,000 \mathrm{~km}^{2}\right)$, are common to inland

\footnotetext{
* Corresponding author. Tel.: +61 297173155 ; fax: +61 297173599.

E-mail addresses: karina.meredith@ansto.gov.au,kmj@ansto. gov.au (K. Meredith).
}

Australia, but their hydrochemical evolution and origin are largely unconstrained. Generally, in saline arid zone groundwater environments traditional tracers such as chloride yield limited information on hydrochemical evolutionary trends because evapo-concentration effects can mask the indicators of groundwater flow paths. It is in these hydrogeological settings that trace element isotopes become particularly useful. Boron isotopes have seen relatively widespread use in hydrogeochemistry (Vengosh et al., 
1994; Barth, 2000 and many others). By comparison, Li isotopes have only recently become more widely used in studies of groundwater hydrology. Whereas several studies have focused on $\mathrm{Li}$ isotopes in basinal brines and similar deep groundwater systems (e.g., Bottomley et al., 1999; Chan et al., 2002; Millot et al., 2007), research making use of the system to investigate the evolution of groundwater chemistry (Tomascak et al., 2003; Millot and Négrel, 2007; Kloppmann et al., 2009; Lemarchand et al., 2010; Négrel et al., 2010) as well as potential anthropogenic impacts (Hogan and Blum, 2003; Kloppmann et al., 2008a,b) has progressively diversified. This study is the first to report much needed $\mathrm{Li}$ isotope data for Australian groundwaters.

The significant relative mass difference between its two stable isotopes make $\mathrm{Li}$ and $\mathrm{B}$ useful for fingerprinting geochemical processes at low temperatures. Light stable isotopes become much more powerful tools when combined with other isotope systematics such as $\mathrm{Sr}$ (e.g., Moriguti and Nakamura, 1998a; Moriguti et al., 2004a). Analysis of these three isotopic systems will yield information on several different hydrogeochemical processes that cannot be discerned by employing some of the more traditional isotopic tracer techniques such as $\delta^{18 / 16} \mathrm{O}, \delta^{2} \mathrm{H}$ and $\delta^{13} \mathrm{C}$. Coupling $\delta^{7} \mathrm{Li}, \delta^{11} \mathrm{~B}$ and ${ }^{87} \mathrm{Sr} /{ }^{86} \mathrm{Sr}$ with groundwater elemental composition can permit clear delineation of the origin of groundwater salinity (marine vs. terrestrial origin), assessment of groundwater mixing, and first order characterisation of the degree of water-sediment interaction.

To begin to understand the hydrogeochemistry of this and other arid zone groundwater environments, a small $250 \mathrm{~km}^{2}$ research site with nested groundwater monitoring wells located adjacent to the Darling River was chosen. Very limited groundwater data is available for this region because it is the most arid and remote area in the Murray-Darling Basin (MDB) and groundwater resources have not been considered important because they are not suitable for domestic or irrigation needs. As a consequence, these aquifers have not been subject to local groundwater exploitation leaving an undisturbed natural system where geochemical tracers can be applied to understand the formation of arid zone groundwater systems.

A multi-tracer approach was employed with $\mathrm{Li}, \mathrm{B}$ and $\mathrm{Sr}$ concentrations and isotopic compositions of the alluvial Darling River groundwater system used to provide further information on the hydrology of this system and to ultimately evaluate groundwater recharge and to identify water-sediment interaction processes leading to the hydrochemical evolution of saline groundwaters in the catchment. This current study builds on data from hydrochemical and isotopic tracers $\left({ }^{14} \mathrm{C}_{\mathrm{DIC}},{ }^{3} \mathrm{H}, \delta^{13} \mathrm{C}_{\mathrm{DIC}}\right.$, $\delta^{18 / 16} \mathrm{O}$ and $\left.\delta^{2} \mathrm{H}\right)$ that have been used previously to understand groundwater/surface water interaction (Meredith et al., 2009), groundwater recharge and age distribution within the study area. It is anticipated that these findings can be extended to other arid to semi-arid zone systems and provide much needed trace element isotopic data for surface water and groundwater studies in the future.

\section{ENVIRONMENTAL SETTING}

The Darling River is located in the northern section of the MDB. The study area, known as Glen Villa, is located approximately $50 \mathrm{~km}$ west of Bourke along the Darling River (New South Wales, Australia; Fig. 1). The area is dominated by arid to semi-arid zone climatic conditions with low rainfall (average $355 \mathrm{~mm} \mathrm{yr}^{-1}$ at Bourke; Meredith et al., 2009). The surficial geology is dominated by vast alluvial plains. Landforms consist of channel and floodplain features with anabranch streams feeding valley margin lakes.

The geology of the study site includes three unconsolidated alluvial aquifer systems; the shallow, intermediate and deep aquifers which are contained within the Narrabri (Quaternary), Gunnedah (Pliocene) and Cubbaroo (Miocene) Formations, respectively. These aquifers are part of an extensive, closed and internally draining groundwater basin. The deep aquifer is only found within a pre-Cenozoic palaeochannel that formed adjacent to the modern Darling River, within the underlying Great Artesian Basin (d' Hautefeuille and Williams, 2003). The other two aquifers are found extensively throughout the site and both have average thicknesses of $30 \mathrm{~m}$. The aquifer units at Glen Villa represent terrestrially sourced sediments originating from distal alluvial fan systems deposited in alternating wet/dry climates. The deeper aquifers have a higher content of sand and gravel and the shallow aquifer has higher clay content than the deeper aquifers (d' Hautefeuille and Williams, 2003).

The Glen Villa area contains a narrow riverine corridor with riparian vegetation such as River Red Gums that run along the Darling River. The presence of the river is the main control on groundwater flow in the horizontal alluvial aquifers of the region. The shallow groundwater system is hydraulically connected to the Darling River, with recharge occurring during high flow periods or overbank flooding events. During the study period the regional groundwater system followed a general down gradient trend towards the Darling River (Fig. 1).

\section{METHODOLOGY}

\subsection{Field techniques}

In August 2007, groundwater samples were collected from 19 wells at seven nested sites with wells located at between 20 and $140 \mathrm{~m}$ bgs (metres below ground surface) (Fig. 1, Table 1). After standing water levels were measured the wells were purged of three well-volumes and until stabilisation of field parameters prior to sampling. Field parameters included: electrical conductivity, oxidation-reduction potential, dissolved oxygen, temperature and $\mathrm{pH}$.

Groundwater samples were collected from an in-line, $0.45 \mu \mathrm{m}$, polyethersulphone high capacity filter that was attached to the head of a submersible pump. For full details of the methodology for sample collection and analyses, except for determination of $\mathrm{Li}$ and $\mathrm{B}$ contents and the isotope analyses of $\mathrm{Li}, \mathrm{B}$ and $\mathrm{Sr}$, readers should refer to Meredith et al. (2012). Samples used to determine $\mathrm{Li}$ and $\mathrm{Sr}$ contents 


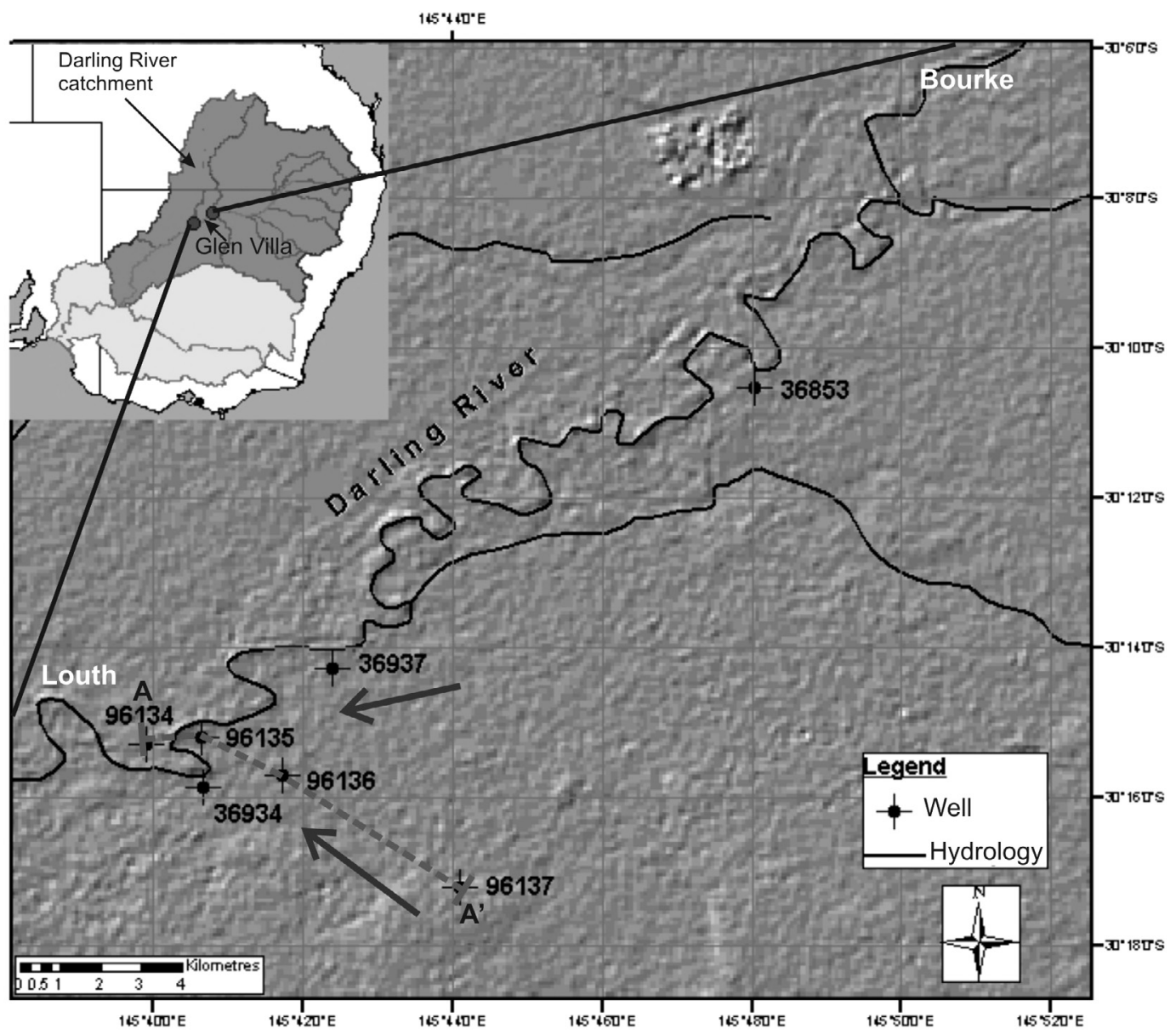

Fig. 1. Location of the Glen Villa study site (dashed lines show the location of cross section $\mathrm{A}-\mathrm{A}^{\prime}$ ) with reference to the limits of the MurrayDarling Basin (left top corner insert: light grey + dark grey extent) and the Darling River catchment (left top corner insert: dark grey extent). Arrows show the generalised groundwater flow direction at the site.

and isotope values were collected in pre-cleaned 125 and $250 \mathrm{~mL}$ high density polyethylene (HDPE) bottles, respectively, and acidified with double distilled nitric acid. Samples used for B analysis were collected in separate pretreated $60 \mathrm{~mL}$ HDPE bottles. For these samples, acidification down to $\mathrm{pH}<2$ was undertaken using low boron blank hydrochloric acid (Nakamura et al., 1992) instead of nitric acid in order to avoid decomposition of mannitol, which was used for suppression of boron evaporation during pre-treatment.

\subsection{Analytical techniques}

The wet chemical treatments for determination of $\mathrm{Li}$ and $\mathrm{B}$ contents and $\mathrm{Li}, \mathrm{B}$ and $\mathrm{Sr}$ isotope values were undertaken at the Pheasant Memorial Laboratory (PML) for Geochemistry and Cosmochemistry, Institute for Study of the Earth's Interior, Okayama University at Misasa, Japan and followed the methods outlined in Nakamura et al. (2003). Strontium, Cl and radiocarbon analysis were determined at Australian Nuclear Science and Technology Organisation by inductively coupled plasma-atomic emission spectroscopy and radiocarbon by accelerator mass spec- trometry according to the methods presented in Meredith et al. (2012). Lithium and B contents were measured by quadrupole inductively coupled plasma mass spectrometer using an Agilent $7500 \mathrm{cs}$ system, following the procedures of Moriguti et al. (2004b) and Lu et al. (2007). The typical analytical errors ( $2 \sigma$ reproducibility) were $<2 \%$ and $<3 \%$ for Li and B, respectively.

Chemical separation processes for $\mathrm{Li}, \mathrm{B}$ and $\mathrm{Sr}$ isotope analyses followed those published by Moriguti and Nakamura (1998b), Nakamura et al. (1992) and Yoshikawa and Nakamura (1993), respectively. Determination of Li isotope ratio was performed using multi-collector inductively coupled plasma mass spectrometer (MC-ICP-MS; Finnigan Neptune), following Tang et al. (2007). Measurement of $\mathrm{B}$ and $\mathrm{Sr}$ isotope ratios were undertaken using thermal ionization mass spectrometer (TIMS; Finnigan MAT261 and MAT262) in static multicollection mode following the methods described in Nakano and Nakamura (1998). Isotope fractionation of $\mathrm{Sr}$ during the analyses was corrected to ${ }^{86} \mathrm{Sr} /{ }^{88} \mathrm{Sr}=0.1194$.

The $\mathrm{Li}$ and $\mathrm{B}$ isotopic compositions are presented as per mil $(\%)$ deviation from the isotopic standard (Li: NIST LSVEC; B: NIST SRM951); thus $\delta^{7} \mathrm{Li}=$ 
Table 1

Hydrochemical and isotope data for groundwaters, and a representative river water sample from the Glen Villa site.

\begin{tabular}{|c|c|c|c|c|c|c|c|c|c|c|c|c|c|c|c|c|}
\hline ID & Date & $\begin{array}{l}\text { Water } \\
\text { type }\end{array}$ & $\begin{array}{l}\text { Elevation } \\
\text { (m asl) }\end{array}$ & $\begin{array}{l}\text { Distance } \\
(\mathrm{km})\end{array}$ & $\begin{array}{l}\text { Depth } \\
\text { (m bgs) }\end{array}$ & $\begin{array}{l}\text { Total } \\
\text { hydraulic } \\
\text { head (m asl) }\end{array}$ & $\begin{array}{l}\operatorname{TDS}_{\mathrm{cal}} \\
\left(\mathrm{mg} \mathrm{L}^{-1}\right)\end{array}$ & $\mathrm{pH}$ & $\begin{array}{l}\mathrm{Cl} \\
(\mathrm{mM})\end{array}$ & $\begin{array}{l}\mathrm{Li} \\
(\mu \mathrm{M})\end{array}$ & $\begin{array}{l}\text { B } \\
(\mu \mathrm{M})\end{array}$ & $\begin{array}{l}\mathrm{Sr} \\
(\mu \mathrm{M})\end{array}$ & $\begin{array}{l}\delta^{7} \mathrm{Li} \\
(\%)\end{array}$ & $\begin{array}{l}\delta^{11} \mathrm{~B} \\
(\%)\end{array}$ & ${ }^{87} \mathrm{Sr} /{ }^{86} \mathrm{Sr}$ & $\begin{array}{l}\mathrm{Age}^{\mathrm{a}} \\
(\mathrm{ka})\end{array}$ \\
\hline DR08 & $26 / 08 / 2007$ & $\begin{array}{l}\text { River } \\
\text { water }\end{array}$ & N/A & 0 & 0 & N/A & 372 & 8.16 & 1.7 & 0.2 & 2.8 & 3.8 & 26.9 & N/A & 0.707179 & \\
\hline GW036853/1 & $25 / 08 / 2007$ & Dilute & 104.1 & $<0.6$ & 16 & 90.7 & 577 & 6.66 & 2.5 & 0.4 & 4.6 & 3.8 & 13.8 & N/A & 0.707656 & M \\
\hline GW036853/2 & $24 / 08 / 2007$ & Saline & 104.0 & $<0.6$ & 43 & 90.7 & 23219 & 6.32 & 341.3 & 10.1 & 79.5 & 259.1 & 10.6 & 47.8 & 0.707938 & 29.3 \\
\hline GW036853/3 & $25 / 08 / 2007$ & Saline & 104.1 & $<0.6$ & 126 & 90.7 & 29900 & 6.41 & 431.6 & 12.4 & 94.3 & 303.6 & 7.9 & 44.7 & 0.708642 & 19.4 \\
\hline GW036934/1 & $23 / 08 / 2007$ & Dilute & 100.1 & $<0.6$ & 13 & 89.2 & 856 & 6.29 & 7.4 & 1.5 & 3.7 & 9.7 & 10.4 & N/A & 0.708875 & $\mathrm{M}$ \\
\hline GW036934/2 & $23 / 08 / 2007$ & Saline & 100.1 & $<0.6$ & 39 & 89.6 & 34238 & 6.38 & 479.5 & 17.6 & 189.6 & 263.6 & 8 & 50.2 & 0.710017 & 7.4 \\
\hline GW036934/3 & $23 / 08 / 2007$ & Saline & 100.1 & $<0.6$ & 72 & 89.5 & 33708 & 6.41 & 456.9 & 21 & 197 & 264.8 & 8.4 & 50.1 & 0.710258 & 9.3 \\
\hline GW036937/1 & $23 / 08 / 2007$ & Dilute & 101.7 & $<0.6$ & 17 & 90.2 & 5822 & 6.54 & 78.7 & 3.5 & 33.2 & 48.8 & 5.8 & 46.6 & 0.708433 & SM \\
\hline GW036937/2 & $24 / 08 / 2007$ & Saline & 101.7 & $<0.6$ & 43 & 89.9 & 27840 & 6.44 & 389.3 & 15.1 & 118.4 & 270.5 & 5.8 & 49.3 & 0.708784 & 10.7 \\
\hline GW036937/3 & $23 / 08 / 2007$ & Saline & 101.7 & $<0.6$ & 110 & 89.7 & 35020 & 6.37 & 490.8 & 17.7 & 180.4 & 311.6 & 8.1 & 47.1 & 0.709248 & 6.6 \\
\hline GW096134/1 & $25 / 08 / 2007$ & Saline & 101.2 & $<0.6$ & 32 & 89.9 & 37153 & 6.41 & 578.2 & 16.6 & 78.1 & 394.9 & 9.4 & 49.4 & 0.708039 & 7 \\
\hline GW096135/1 & $24 / 08 / 2007$ & Saline & 100.4 & $<0.6$ & 16 & 89.1 & 28496 & 6.41 & 462.6 & 9.6 & 54.3 & 219.1 & 13.7 & 50.7 & 0.708056 & SM \\
\hline GW096135/2 & $24 / 08 / 2007$ & Saline & 100.4 & $<0.6$ & 28 & 89.6 & 33227 & 6.36 & 479.5 & 15 & 143.4 & 308.1 & 9 & 48.5 & 0.708874 & 6.3 \\
\hline GW096135/3 & $24 / 08 / 2007$ & Saline & 100.4 & $<0.6$ & 42 & 89.7 & 33468 & 6.35 & 485.2 & 15.7 & 160 & 294.5 & 7.2 & 47.9 & 0.709144 & 6.8 \\
\hline GW096136/1 & $21 / 08 / 2007$ & Saline & 101.2 & 2.5 & 17 & 89.8 & 30514 & 6.41 & 428.7 & 16 & 146.1 & 287.6 & 7.8 & 44.9 & 0.708838 & SM \\
\hline GW096136/2 & $22 / 08 / 2007$ & Saline & 101.2 & 2.5 & 37 & 89.8 & 34253 & 6.24 & 496.4 & 17.3 & 153.5 & 312.7 & 6.1 & 44.4 & 0.708792 & SM \\
\hline GW096136/3 & $21 / 08 / 2007$ & Saline & 101.2 & 2.5 & 119 & 90.1 & 33337 & 6.4 & 454.1 & 29.4 & 156.3 & 246.5 & 8.6 & 52.8 & 0.711619 & 16.8 \\
\hline GW096137/1 & $22 / 08 / 2007$ & Saline & 101.3 & 7 & 15 & 90.0 & 36710 & 6.74 & 456.9 & 6.6 & 361.7 & 216.8 & 14 & 52.6 & 0.711635 & SM \\
\hline GW096137/2 & $22 / 08 / 2007$ & Saline & 101.4 & 7 & 22 & 90.0 & 38579 & 6.55 & 473.9 & 7.2 & 351.5 & 229.4 & 13.4 & 53.9 & 0.711572 & 0.1 \\
\hline GW096137/3 & $22 / 08 / 2007$ & Saline & 101.4 & 7 & 52 & 90.5 & 22358 & 6.57 & 310.3 & 6.6 & 97.1 & 138.1 & 16.2 & 48.8 & 0.713091 & 36.8 \\
\hline Seawater & & Seawater & & & 0 & & 33488 & & 550 & 29 & 407 & 91.3 & 31 & 38.9 & 0.709 & \\
\hline
\end{tabular}

M, modern $(<0.06 \mathrm{ka})$; SM, sub-modern $(>0.06$ but $<1 \mathrm{ka})$; N/A, volume collected was not sufficient for analysis; BDL, below detection limit.

${ }^{a}$ Tamers ${ }^{14} \mathrm{C}$ corrected age. 
$\left(\left({ }^{7} \mathrm{Li} /{ }^{6} \mathrm{Li}\right)_{\text {sample }} /\left({ }^{7} \mathrm{Li} /{ }^{6} \mathrm{Li}\right)_{\text {standard }}-1\right) \times 1000$ and $\quad \delta^{11-}$ $\mathrm{B}=\left(\left({ }^{11} \mathrm{~B} /{ }^{10} \mathrm{~B}\right)_{\text {sample }} /\left({ }^{11} \mathrm{~B} /{ }^{10} \mathrm{~B}\right)_{\text {standard }}-1\right) \times 1000$. Sample analyses were bracketed by analyses of NIST L-SVEC in $\mathrm{Li}$ isotope analyses as performed in Tomascak et al. (1999). $\delta^{7} \mathrm{Li}$ value of standard rock sample, GSJ JB-2, during the course of this study was $4.93 \pm 0.45 \%$ o $(2 \sigma, n=8)$, consistent with values obtained by TIMS, within analytical error $(4.9 \pm 0.7 \% 2 \sigma$ reproducibility). Measured ratios of standard materials for B (NIST SRM951) and $\mathrm{Sr}$ isotopes (NIST SRM987), were ${ }^{11} \mathrm{~B} /{ }^{10} \mathrm{~B}=4.0472 \pm 35(2 \sigma, n=7)$ and ${ }^{87} \mathrm{Sr} /{ }^{86} \mathrm{Sr}=0.710243 \pm 12(2 \sigma, n=15)$, respectively, during the course of this study. River and groundwater sample solutions used in each elemental separation contained 1.3 to $1.5 \mu \mathrm{g} \mathrm{Li}, \sim 30 \mathrm{ng} \mathrm{B}$, and 1-2.7 $\mu \mathrm{g} \mathrm{Sr}$. Total procedural blanks for $\mathrm{Li}, \mathrm{B}$ and $\mathrm{Sr}$ were $4 \mathrm{pg}, 7 \mathrm{ng}$ and $13 \mathrm{pg}$, respectively. Boron blanks are higher than others, however, two separately measured B isotope ratios of a seawater sample from the Mariana Trough (W34-5, $20^{\circ} 58.99^{\prime} \mathrm{N}, 143^{\circ} 24.68^{\prime} \mathrm{E}, 4871-\mathrm{m}$ depth) were 39.1 and $38.7 \%$, consistent with 39.7 and $39.9 \%$ obtained by Nakamura et al. (1992) within $2 \sigma$ reproducibility, $\pm 0.5 \%$ (Nakano and Nakamura, 1998). Lithium and Sr blanks are almost four and five order magnitudes lower than sample size, respectively. Therefore, blank correction is not necessary. In Li blank analysis, TIMS (Finnigan MAT261) was used by following the analytical method shown in Moriguti and Nakamura (1998b).

\section{RESULTS}

\subsection{River water}

The Darling River water was found to have low trace elements contents $(\mathrm{Li}=0.2, \quad \mathrm{~B}=2.8 \quad$ and $\left.\mathrm{Sr}=3.8 \mu \mathrm{mol} \mathrm{L}^{-1}\right)$. The $\mathrm{Li}$ content is consistent with the global average $\left(0.215 \mu \mathrm{mol} \mathrm{L}^{-1}\right.$; Huh et al., 1998) and $\delta^{7} \mathrm{Li}$ was high $(+26.9 \%)$ compared to average upper continental crust $(0 \pm 2$; Teng et al., 2004) but close to the reported average riverine value $(+23.5$; Huh et al., 1998). The obtained ${ }^{87} \mathrm{Sr} /{ }^{86} \mathrm{Sr}$ ratio $(0.707179)$ was slightly lower than those values reported for the Darling River at Burtundy (0.708-0.709) (Douglas et al., 1999) (Table 1). The B isotopic analysis of river water was not undertaken because volume of this low boron content sample was not enough for precise $\mathrm{B}$ isotope analysis.

\subsection{Groundwater}

Most groundwaters sampled from the Glen Villa site were found to be extremely saline (average $\mathrm{TDS}=32,000 \mathrm{mg} \mathrm{L}^{-1} ; n=16$ ) and were commonly $\mathrm{Na}-$ Cl-rich, with lesser concentrations of $\mathrm{Mg}^{2+}$ and $\mathrm{SO}_{4}{ }^{2-}$. Shallow groundwaters $(<17 \mathrm{~m} \mathrm{bgs})$ located close to the river $(<0.6 \mathrm{~km})$ generally had lower ion concentrations than all other samples. Groundwaters located $<0.6 \mathrm{~km}$ from the river were divided into dilute and saline categories based on TDS values $\left(>10,000 \mathrm{mg} \mathrm{L}^{-1}\right.$ considered saline; Table 1$)$. Dilute groundwaters located $<0.6 \mathrm{~km}$ from the river consistently had the lowest concentrations of trace elements. Groundwaters located 2.5 and $7 \mathrm{~km}$ from the river were found to be saline, irrespective of depth. Saline groundwaters had lower concentrations of $\mathrm{Li}$ and $\mathrm{B}$ but higher $\mathrm{Sr}$ concentrations compared to seawater. Groundwater age among the saline samples, estimated using radiocarbon, varied from modern to $>30 \mathrm{ka}$ and did not show obvious correlation with depth $\left(r^{2}=0.1\right)$.

\subsubsection{Lithium}

Saline groundwaters generally had much lower concentrations of Li relative to seawater but were generally 100 times greater than the river water. Lithium concentrations ranged from 0.4 (most dilute sample located $<0.6 \mathrm{~km}$ from the river) to $29.4 \mu \mathrm{mol} \mathrm{L}^{-1}$ (deepest sample located $\sim 2.5 \mathrm{~km}$ from the river) and generally increased with depth. The $\delta^{7} \mathrm{Li}$ of groundwaters were found to vary from $+5.8 \%$ (dilute sample located $<0.6 \mathrm{~km}$ from the river) to $+16.2 \%$ (deepest sample located $7 \mathrm{~km}$ from the river), with an average value of $+9.7 \%$ o $(n=19)$.

\subsubsection{Boron}

Boron concentrations in groundwaters ranged from 3.7 (dilute sample located $<0.6 \mathrm{~km}$ from the river) to $361.7 \mu \mathrm{mol} \mathrm{L}^{-1}$ (shallow sample located $7 \mathrm{~km}$ from the river). Saline groundwaters had much lower B concentrations than seawater but were $\sim 60$ times greater than the river water. Boron concentrations were higher in shallow saline groundwater than in dilute samples, a trend similar to that observed for $\mathrm{Li}$. The $\delta^{11} \mathrm{~B}$ values were higher than seawater, ranging from $+44.4 \%$ o to $+53.9 \%$ o (average: $+48.8 \%$, $n=17$ ). Shallow groundwaters located $7 \mathrm{~km}$ from the river had the highest $\delta^{11} \mathrm{~B}$ values and $\mathrm{B}$ concentrations.

\subsubsection{Strontium}

Strontium concentrations in the groundwaters were variable, ranging from 3.8 (dilute sample located $<0.6 \mathrm{~km}$ from the river) to $394.9 \mu \mathrm{mol} \mathrm{L}^{-1}$ (shallow aquifer located $<0.6 \mathrm{~km}$ from the river) which is $\sim 4$ times higher than seawater. The ${ }^{87} \mathrm{Sr} /{ }^{86} \mathrm{Sr}$ ratios ranged from 0.708 (dilute sample located $<0.6 \mathrm{~km}$ from the river) to 0.713 (deepest sample located $7 \mathrm{~km}$ from the river) with an average value of $0.709(n=19)$. The ${ }^{87} \mathrm{Sr} /{ }^{86} \mathrm{Sr}$ of all groundwater samples were higher than that of the river water.

\section{DISCUSSION}

The elevation in this study area is extremely flat with only $\sim 1 \mathrm{~m}$ difference across the $7 \mathrm{~km}$ transect (i.e. from GW096137 to GW096135) (Table 1). Regional groundwater flow direction is from northeast to southwest and is very subtle with an average hydraulic gradient of $8 \times 10^{-5}$ towards the Darling River. A slight upward hydraulic gradient is experienced in the deeper sections of the alluvial aquifer (i.e. from wells located between 50 and $130 \mathrm{~m} \mathrm{bgs}$ ). Groundwater flow in the vertical and horizontal directions is very low and is representative of a closed, arid, internally draining groundwater basin.

The shallow aquifer is contained within isolated units of sand and/or gravel sediments within a predominantly clayrich system and because of the discontinuous nature of the permeable sediments, a series of localised groundwater 


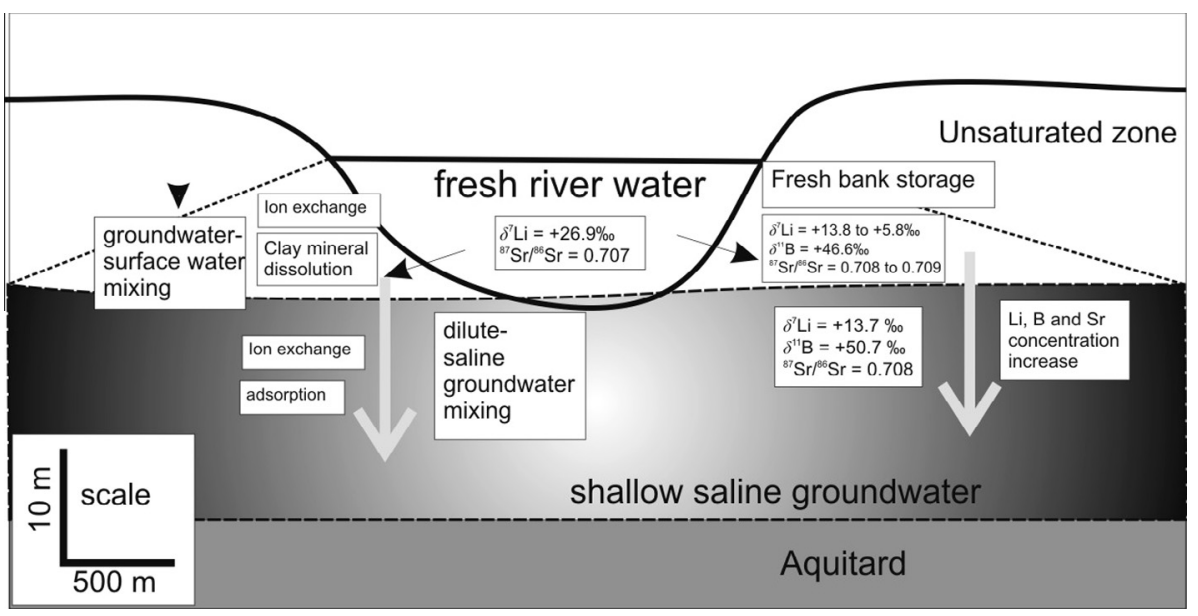

Fig. 2. Schematic illustration of point-sourced recharge near the river channel $(<0.6 \mathrm{~km})$ during high flow periods in the river with average $\delta^{7} \mathrm{Li}, \delta^{11} \mathrm{~B}$ and ${ }^{87} \mathrm{Sr} /{ }^{86} \mathrm{Sr}$ values resulting from each hydrochemical process. The small dotted line adjacent the river channel represents the groundwater level from fresh bank storage. The larger dotted line indicates the location of the flat lying saline groundwater table.

systems with different hydrochemical facies have evolved in the upper sections of the alluvium $(0-20 \mathrm{~m}$ bgs). The water level of the shallow aquifer dissects the base of the river channel indicating that close to the river $(<0.6 \mathrm{~km})$ the shallow aquifer is in hydraulic connection with the Darling River.

Two main mechanisms of groundwater recharge to the shallow aquifer exist in the Glen Villa area. Firstly, minor inputs derive from diffuse local rainfall recharge across the floodplain during high rainfall events. Secondly, and more sporadically, recharge into the floodplain near the river $(<0.6 \mathrm{~km})$ from bank flow originating from the Darling River during flood events. The presence of fresh water lenses at some locations in the shallow aquifer adjacent to the river confirms this process.

The elevated salinity of the deeper regional groundwater system provides a distinct contrast between the fresh bank storage recharge adjacent the Darling River (i.e. groundwater-surface water interaction). This process can be recognised by low ionic concentrations in the groundwater, particularly $\mathrm{Cl}^{-}$concentration (Fig. 2). Groundwater sample $36853 / 1$ was found to have the lowest $\mathrm{Cl}^{-}$concentration (2.5 mmol L ${ }^{-1}$; Table 1). Samples 36934/1, 36937/1 and $96135 / 1$, which are all located close to the river $(<0.6 \mathrm{~km})$, increase in $\mathrm{Cl}^{-}$concentration suggesting varying degrees of hydraulic connection between the river and shallow groundwater system.

\subsection{Groundwater recharge near the river channel}

\subsubsection{Recharge water signal}

The Darling River has an elevated $\delta^{7} \mathrm{Li}(+26.9 \%)$ and its ${ }^{87} \mathrm{Sr} /{ }^{86} \mathrm{Sr}$ is less radiogenic $(0.707179)$ than the average seawater value for the Phanerozoic (0.709; Burke et al., 1982). Given that there are uncertainties when regarding a single river water sample, and in the absence of detailed time-series surface-groundwater studies against which to compare, interpretation of the isotopic composition of the Darling River sample remains speculative and requires further re- search in this study area. However, given these limitations, some key processes can be evaluated and related back to the isotopic evolution of groundwater in this system.

Several studies have demonstrated that $\mathrm{Li}$ isotopic compositions of river waters taken at one location over a period of years are generally consistent, with $<6 \%$ total variability (Tomascak et al., 2003; Kisakurek et al., 2005; Lemarchand et al., 2010; Négrel et al., 2010). The high $\delta^{7} \mathrm{Li}$ of the Darling River water sample $(10.7 \%$ greater than the heaviest groundwater sample) is not unusual. River waters are generally reported as isotopically heavy in $\mathrm{Li}$, irrespective of the lithology or catchment area drained, and this is reflected in the global flow-weighted river mean $\delta^{7} \mathrm{Li}$ of $+23.5 \%$ o (Huh et al., 1998).

In spite of variability, largely owing to local conditions, the $\delta^{7} \mathrm{Li}$ of river waters is fairly consistent from one area to another. However, rainwater appears to be much more variable. Although it had been assumed that Li in rainfall, at least in coastal regions, is dominated by marine aerosols (e.g., You et al., 2004), the lone study to examine rainwater $\mathrm{Li}$ isotopes comprehensively (Millot et al., 2010) found that this is not strictly the case. Although rainfall in France showed a Li isotope effect from proximity to marine water masses, continental contributors also were clearly important. For example, rainfall in two coastal cities maintained an average $\delta^{7} \mathrm{Li}$ of +22.7 (Millot et al., 2010), which is $8.3 \%$ and $4.2 \%$ lighter than seawater and the Darling River sample. This therefore implies that the rainfall signature maybe be just as influential on the observed river water Li signature. Nonetheless, ${ }^{87} \mathrm{Sr} /{ }^{86} \mathrm{Sr}$ is lower than modern seawater, suggesting marine atmospheric deposition is not the main source of $\mathrm{Sr}$ for the Darling River. It is plausible that a less radiogenic carbonate and/or evaporite source exists. Calcretes and evaporite minerals are prevalent in the soils of the Darling River catchment and dissolution of these minerals may have a strong influence on the observed $\mathrm{Li}$ and $\mathrm{Sr}$ signatures in the river water.

Anthropogenic sources of trace elements have been considered in this catchment. This is a highly regulated dryland 
river system where opportunistic irrigation occurs during high flow periods from the river $\sim 55 \mathrm{~km}$ upstream at Bourke. Within the immediate study area no commercial agriculture occurs. Therefore, the input of trace elements from sources other than the catchment geology would be highly unlikely. The most influential component of trace element input to the river is from saline groundwater discharge during low flow conditions in the river (Meredith et al., 2009). The source of $\mathrm{Li}, \mathrm{B}$ and $\mathrm{Sr}$ in the river is believed to be from the dissolution of minerals and weathering of catchment bedrock during overland flow.

During high flow conditions in the river, such as those observed, the initial recharge water for bank storage is expected to have a starting isotope value of $\sim+27 \%$ for $\delta^{7} \mathrm{Li}$ and 0.707 for ${ }^{87} \mathrm{Sr} /{ }^{86} \mathrm{Sr}$. Even though $\delta^{11} \mathrm{~B}$ was not analysed, other riverine studies found that $\delta^{11} \mathrm{~B}$ values are related to catchment lithology. Rivers draining volcanic bedrock were isotopically lighter $(-1.8 \%$ to $+5.0 \%)$ than those draining silicate-rich lithologies ( $+20.3 \%$ to $24.3 \%$ ) (Lemarchand and Gaillardet, 2006). Similar variations were found for the Himalayan Rivers $(-7.0 \%$ to $+24.0 \%$ o (Rose et al., 2000). It is expected that the Darling River water would fall towards the more enriched values in those observed data. Darling River, water can be composed of up to $99 \%$ groundwater depending on flow conditions (Meredith et al., 2009). However, when bank recharge occurs in the alluvium, such as what was observed during this study, the river water will be dominated by rainwater that has fallen in the catchment area and been transported via overland flow. During its transit to the river channel, river water will interact with the bedrock lithology producing chemistry similar to the dilute groundwater sample analysed $(36937 / 1:+46.6 \%)$.

Initial recharge waters for groundwaters originate from diffuse rainfall input located away from the river (i.e. $>1 \mathrm{~km}$ ) with no hydraulic connection with the river, are expected to have slightly more depleted starting isotope values $\left(\delta^{7} \mathrm{Li} \sim+23 \%\right.$ o $)$ based on rainfall values of previous studies (Millot et al., 2010). The $\delta^{11} \mathrm{~B}$ values for rainwater are likely to be low and in the absence of specific rainfall data from the Darling catchment, were assumed to be similar to those found in Himalayan rainwater (mean $\sim 5 \%$; Rose et al., 2000). Strontium in rainfall would be expected to be predominantly from an oceanic aerosol source and have ${ }^{87} \mathrm{Sr} /{ }^{86} \mathrm{Sr} \sim 0.709$. Therefore, river water and rainwater recharge signatures would be similar, with the exception of $\delta^{11} \mathrm{~B}$ values.

\subsubsection{Dilute groundwaters}

Areas of bank storage recharge occur closest to the river channel $(<0.6 \mathrm{~km})$ in the shallow aquifer at between 13 and $17 \mathrm{~m} \mathrm{bgs}$ and form dilute groundwater. Considering the proximity to the river and the distinct changes in groundwater chemistry, it can be assumed that trace element isotopes would be an effective tracer of water-sediment interaction during groundwater recharge.

Of the three dilute samples, increasing elemental concentrations (and salinity) correlate with increasingly lighter $\delta^{7} \mathrm{Li}$ signatures. This trend ( $\delta^{7} \mathrm{Li}$ vs. $\left.1 / \mathrm{Li} ; r^{2}=0.98\right)$ may reflect mixing between a saline end-member composition, enriched in light $\mathrm{Li}$, and river water. If this was a simple two- component mixing process, it would require $<4 \% \mathrm{Li}$ from these dilute groundwaters to be derived from fresh river recharge, but the saline end-member would be isotopically light $\left(\delta^{7} \mathrm{Li} \sim+5 \%\right.$ oo $)$

The Li isotope relationship between surface and groundwater at Glen Villa bears overall similarity to that described in the literature for other catchments. The $\delta^{7} \mathrm{Li}$ offset between the river water and the most dilute groundwater sample is $13.1 \%$. In the few cases where groundwater and surface water have been analysed for $\delta^{7} \mathrm{Li}$ in the same system, the comparison show no simple pattern. The $\delta^{7} \mathrm{Li}$ offset between spring water and river water in Iceland reported by Pogge von Strandmann et al. (2006) is $2.5 \%$. In northwestern France the offset, based on a more comprehensive suite of groundwater samples from springs, was 5.9\% (Lemarchand et al., 2010). In both of these cases the river water average was isotopically heavier than the groundwater. The previous studies concluded that the offset between $\mathrm{Li}$ isotope signatures of fresh recharge and variably saline groundwater derives from water-rock interaction which varies spatially and/or temporally.

Lithium isotope trends suggest water-sediment interaction has an integral part in the evolution of dilute groundwaters after recharge. Lemarchand et al. (2010) found that most $(>70 \%)$ of the $\mathrm{Li}$ in soils is derived from mineral dissolution and exchange. Hence, if their results are applicable to the aquifer systems in this study, it can be concluded that little of the original isotopic character of the river water will be retained after even short-term interaction with sediments in the subsurface. Consequently, the prominent isotopic composition of river water would be rapidly modified once fresh bank storage has infiltrated the sediments of the shallow aquifer, resulting in a lower $\delta^{7} \mathrm{Li}$ signature $(+13.8$ to $+5.8 \%$ o $)$. The range in $\delta^{7} \mathrm{Li}$ of the dilute samples $(8.0 \%)$, approaches the isotopic range exhibited by the entire data set $(10.4 \%)$. The large variation requires that the specific minerals participating in exchange reactions (each with distinctive isotopic fractionation factors) along the flow path varied substantially within the unsaturated zone. As river water enters the shallow aquifer, forming dilute modern groundwaters, a decrease in $\delta^{7} \mathrm{Li}$ is most likely attributable to the dissolution of clay minerals in the unsaturated zone (Fig. 2).

The only dilute sample to be analysed for $\delta^{11} \mathrm{~B}(36937 / 1$; $46.6 \%$ o is $7.7 \%$ enriched relative to seawater and $\sim 57 \%$ relative to the continental crust $(-10 \pm 2 \%$; Chaussidon and Albarede, 1992). Fractionation processes leading to $\delta^{11} \mathrm{~B}$ enrichment in seawater relative to the continental crust include: adsorption of riverine B onto clays (Schwarcz et al., 1969; Palmer et al., 1987) and hydrothermal alteration of oceanic crust (Spivack and Edmond, 1987). The elevated $\delta^{11} \mathrm{~B}$ values at Glen Villa make it tempting to assume that $\mathrm{B}$ has a marine origin. However, no definitive explanation on $\delta^{11} \mathrm{~B}$ enrichment in the Glen Villa groundwaters can be given due to the absence of a river water sample. It is proposed here that water-sediment interaction overtime can explain the enriched values in groundwater. Boron isotopes can fractionate during sorption reactions within clay minerals (Palmer et al., 1987), a process that is likely to be very important in this alluvial aquifer because of its high clay content. During these reactions, ${ }^{10} \mathrm{~B}$ can be incorporated into the clay 
minerals, leading to elevated $\delta^{11} \mathrm{~B}$ values in solution. Adsorption processes can lead to a shift of $-25 \%$ for clays to $-40 \%$ for oxides at $\mathrm{pH} 8$, to the relative enrichment of ${ }^{11} \mathrm{~B}$ in solution (Palmer et al., 1987; Lemarchand et al., 2005). In this system, river water recharges the alluvium forming dilute groundwater, the water/sediment ratio increases and so to would the amount of $\mathrm{B}$ adsorbing onto the sediment surfaces leading to an increase in $\delta^{11} \mathrm{~B}$ values in the groundwater.

Further evidence of water-sediment interaction overprinting the initial river water signal is observed in an offset in ${ }^{87} \mathrm{Sr} /{ }^{86} \mathrm{Sr}$ values between river water $(0.707)$ and dilute groundwater $(0.708-0.709)$. The addition of slightly more radiogenic $\mathrm{Sr}$ with increase in salinity is observed; the values are slightly lower than seawater and most likely represent the ${ }^{87} \mathrm{Sr} /{ }^{86} \mathrm{Sr}$ associated with clay minerals or carbonate/evaporite minerals found in the shallow alluvium.

\subsection{Geochemical relationships and evolution of groundwater}

The initial recharge water of the shallow aquifer near the river $(<0.6 \mathrm{~km})$ has a hydrochemical signature that can be traced back to river water. However, the initial water chemistry and subsequent hydrochemical evolution of deep and more distal waters from the river $(>1 \mathrm{~km})$ are less certain. Trace element isotopes have the potential to improve our understanding of the evolution of these saline groundwaters.

The groundwater system at Glen Villa might upon first examination of the elemental data be characterised as a large-scale example of simple mixing. If such a model was indeed representative, the two quasi-end-member compositions would comprise a fresh, surficial recharge component, dominated by rainfall, and a saline component, dominated by mineral dissolution and water-sediment interaction processes. Mixing between these end-members would produce groundwaters that plot along a line of increasing salinity (e.g., $\mathrm{Na}$ versus $\mathrm{Cl}$ ). Such large-scale mixing has been invoked to explain elemental and isotopic compositions of groundwater in other catchments (e.g., Lemarchand et al., 2010). Nonetheless, the applicability of a simple geochemical explanation at Glen Villa breaks down on closer examination. Other element-element relationships show substantial non-linearity (Fig. 3) and element-isotope relations are incompatible with a two-component model (Fig. 4).
Additional evidence that not all saline groundwaters have evolved from the dilute end-member comes from the groundwater residence time $\left({ }^{14} \mathrm{C}\right.$ age $)$ distribution in the aquifers. Samples taken from depths $<25 \mathrm{~m}$ bgs are uniformly young but otherwise depth and groundwater age do not correlate (Fig. 5a). If all the groundwaters had evolved from the dilute to the most geochemically mature water, then correlations between $\mathrm{Li}$ isotope composition and age would exist (Fig. 5b). Groundwaters with longer residence times would have had more opportunity to equilibrate with aquifer minerals, and hence older groundwaters would be expected to bear a more consistent, most likely enriched isotopic signature, distinct from fresh recharge.

The complex elemental and isotopic systematics can be better understood by examining the groundwaters as subsets of samples from different depths and/or distances from the river. When assessed in this way, five sample subsets can be considered independently, three of which have some endmember characteristics. The end-members include: shallow dilute waters from wells proximal to the channel $(<0.6 \mathrm{~km}$, 13-17 m bgs: $n=3$; discussed above), saline groundwaters from wells located the greatest distance from the channel (7 km, 15-52 m bgs: $n=3$ ), and saline deep $(<0.6-2.5 \mathrm{~km}$, $>100$ m bgs: $n=3$ ) groundwaters (Fig. 6).

\subsubsection{Saline groundwaters located close to the river $(<2.5 \mathrm{~km})$}

5.2.1.1. Shallow samples (16-72 $\mathrm{m} \mathrm{bgs})$. The majority of samples, from shallow to intermediate depths from wells within $2.5 \mathrm{~km}$ of the channel $(n=10)$, have compositions that plot intermediate to the modern-dilute, shallow and old-saline, deep end-member groups (Fig. 6) and form clusters on the isotope-element plots (Fig. 4). The generally low $\delta^{7} \mathrm{Li}$ values observed (average: $+8.6 \%$ ) discount $\mathrm{Li}$ from marine sources playing a significant role, considering the $\delta^{7} \mathrm{Li}$ of seawater $(+31.0 \%$ o $)$. The fairly well constrained $\delta^{7} \mathrm{Li}$ values imply the majority of the isotopic fractionation from water-sediment reactions occurs in the top $\sim 20 \mathrm{~m}$ of the aquifer within a distance of $2.5 \mathrm{~km}$ of the river and fractionation in the deeper sections of the aquifer is minor.

The consistently high $\delta^{11} \mathrm{~B}$ (average: $+48.3 \%$ ) of the same samples suggests $\mathrm{B}$ isotope fractionation is related to adsorption processes onto clay minerals, similar to those

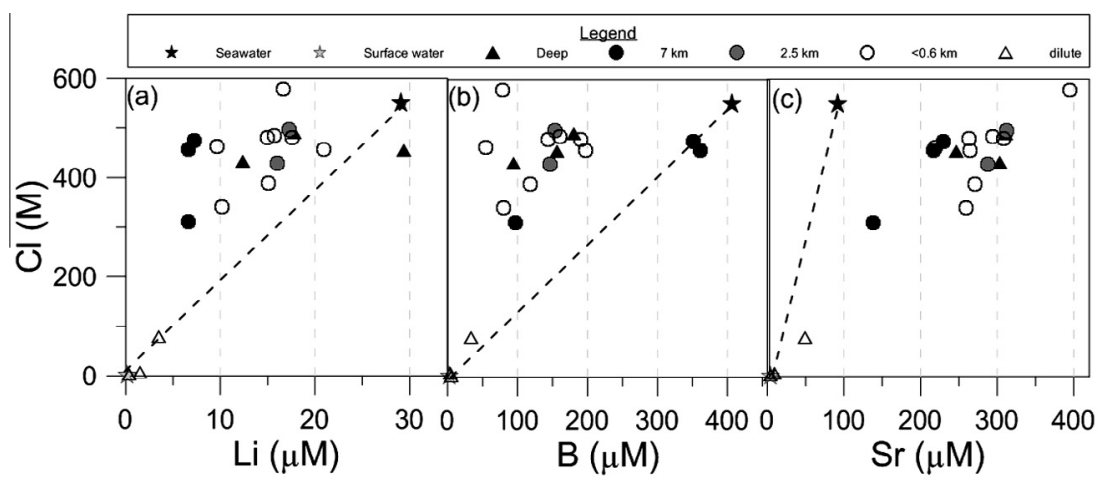

Fig. 3. Bivariate plots of (a) $\mathrm{Cl}$ vs. $\mathrm{Li}$ (b) $\mathrm{Cl}$ vs. $\mathrm{B}$ and (c) $\mathrm{Cl}$ vs. $\mathrm{Sr}$ for waters from the study site. See text for definition of sample groups. Dashed line shows the hypothetical trend of progressive addition of seawater to fresh recharge. 


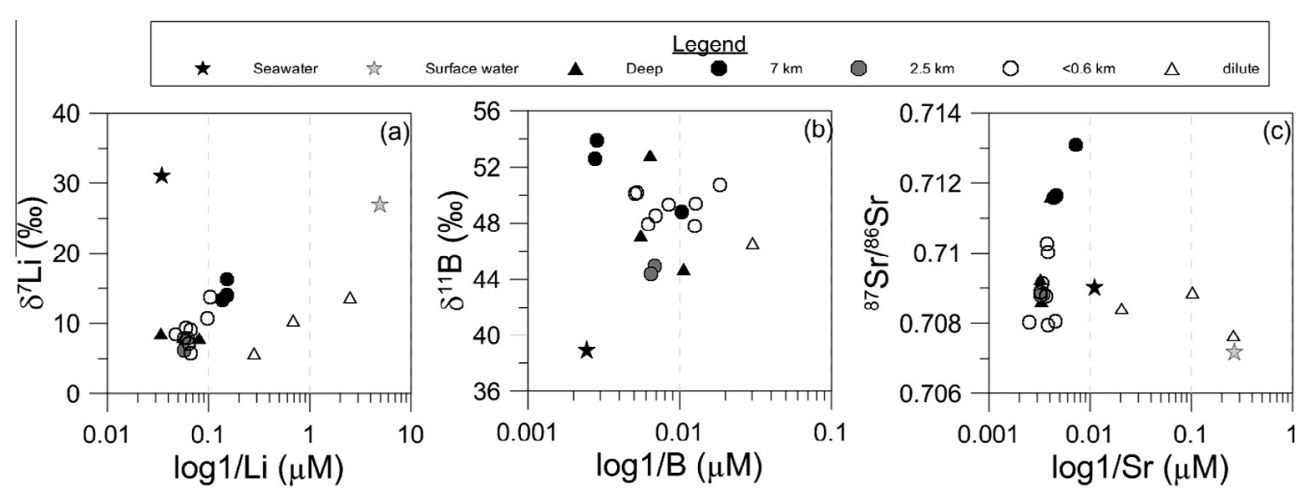

Fig. 4. Bivariate plots of (a) $\delta^{7} \mathrm{Li}$ vs. $\log 1 / \mathrm{Li}$ (b) $\delta^{11} \mathrm{~B}$ vs. $\log 1 / \mathrm{B}$ and (c) ${ }^{87} \mathrm{Sr} /{ }^{86} \mathrm{Sr}$ isotopic ratios vs. $\log 1 / \mathrm{Sr}$ for waters from the study site. These plots demonstrate that simple mixing cannot account for the combined elemental and isotopic variations among the samples.
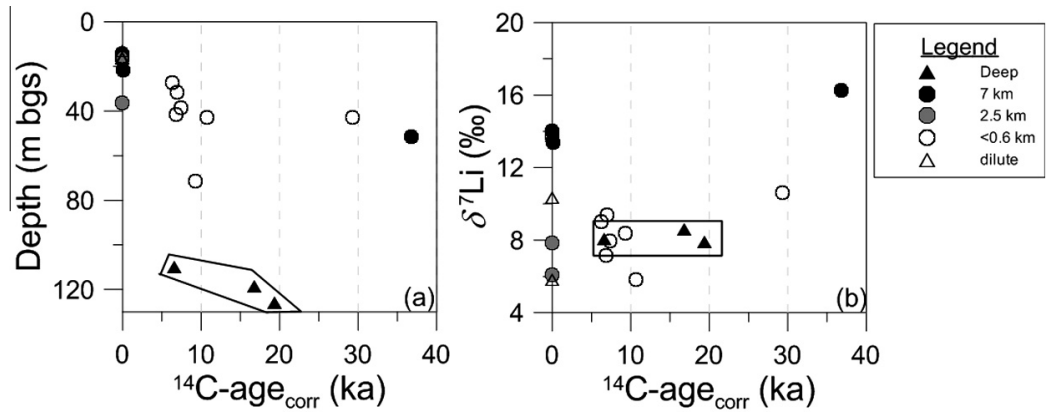

Fig. 5. Bivariate plots of (a) depth vs. corrected ${ }^{14} \mathrm{C}$ age and (b) $\delta^{7} \mathrm{Li}$ vs. corrected ${ }^{14} \mathrm{C}$ age for groundwaters from the study site. Groundwater ${ }^{14} \mathrm{C}$ ages have been corrected for the input of 'dead' carbon using the Tamers method (Tamers, 1975). There is no simple relationship between water age and depth.

processes described for the dilute groundwaters. The major hydrological difference is that bank recharge does not occur and the sediments are not subject to modern river recharge, which would perturb the system moving it to a non-steady state system with respect to B. Perturbations in the system create ideal conditions for further isotopic exchange reactions (Lemarchand and Gaillardet, 2006). However, the elevated $\delta^{11} \mathrm{~B}$ signature could be representative of water-sediment interaction (i.e. exchange processes) that may have been established when the river water inundated the area during much wetter periods than present. It is clear from the enriched $\delta^{11} \mathrm{~B}$ values that exchange reactions still dominate this aquifer and equilibrium between water and sediment for B has not been established.

The average ${ }^{87} \mathrm{Sr} /{ }^{86} \mathrm{Sr}$ value of 0.709 would generally suggest a modern marine $\mathrm{Sr}$ source, but this can be discounted because the study area is located $\sim 800 \mathrm{~km}$ inland. There is no evidence of a palaeo-seawater source because $\delta^{7} \mathrm{Li}$ values are far too low and $\delta^{18 / 16} \mathrm{O}$ and $\delta^{2} \mathrm{H}$ values for the groundwaters have average values of $-4.3 \%$ and $-34.0 \%$, respectively, which are much lighter than seawater $(0 \%)$. As seen with the $\mathrm{Li}$ and $\mathrm{B}$ it is proposed that water-sediment reactions involving clay mineral are also responsible for the increase in $\mathrm{Sr}$ concentrations in these groundwaters.

5.2.1.2. Deep samples ( $>100 \mathrm{mbgs}$ ). The three deepest $(>100 \mathrm{mbgs})$ saline groundwaters all located within
$2.5 \mathrm{~km}$ of the channel, have correspondingly old ${ }^{14} \mathrm{C}$ ages $\left(>5 \mathrm{ka}\right.$ ) and similar $\delta^{7} \mathrm{Li}$ values (around $+8 \%$ ) (Fig. $5 \mathrm{~b}$ ). These samples also have $\mathrm{B}$ and $\mathrm{Sr}$ concentrations and isotopic composition averages that are all intermediate relative

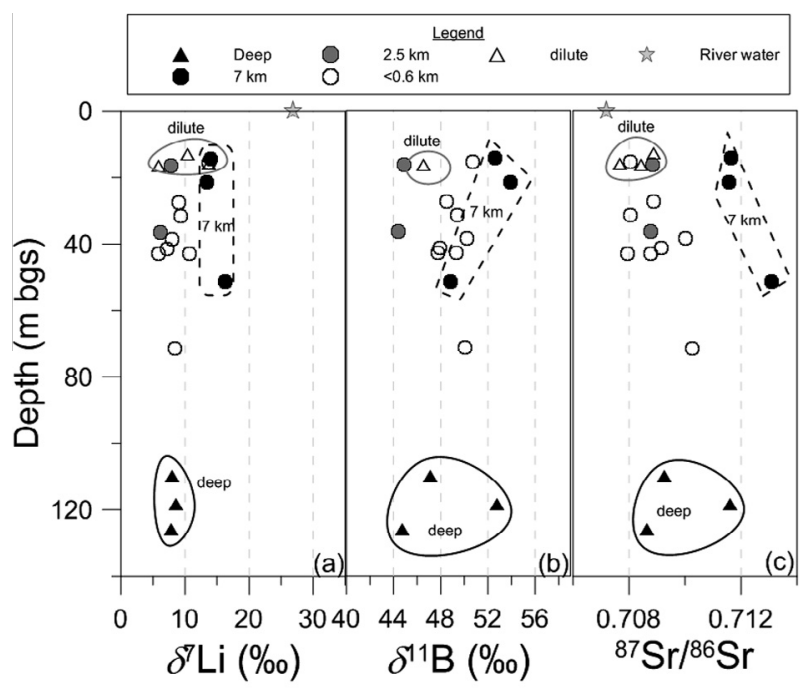

Fig. 6. Bivariate plots of depth vs. (a) $\delta^{7} \mathrm{Li}$ (b) $\delta^{11} \mathrm{~B}$ and (c) ${ }^{87} \mathrm{Sr} /{ }^{66} \mathrm{Sr}$ for waters from the study site. Showing how the three deepest samples (black circle) generally encompass the range for all other groundwaters from the area. 


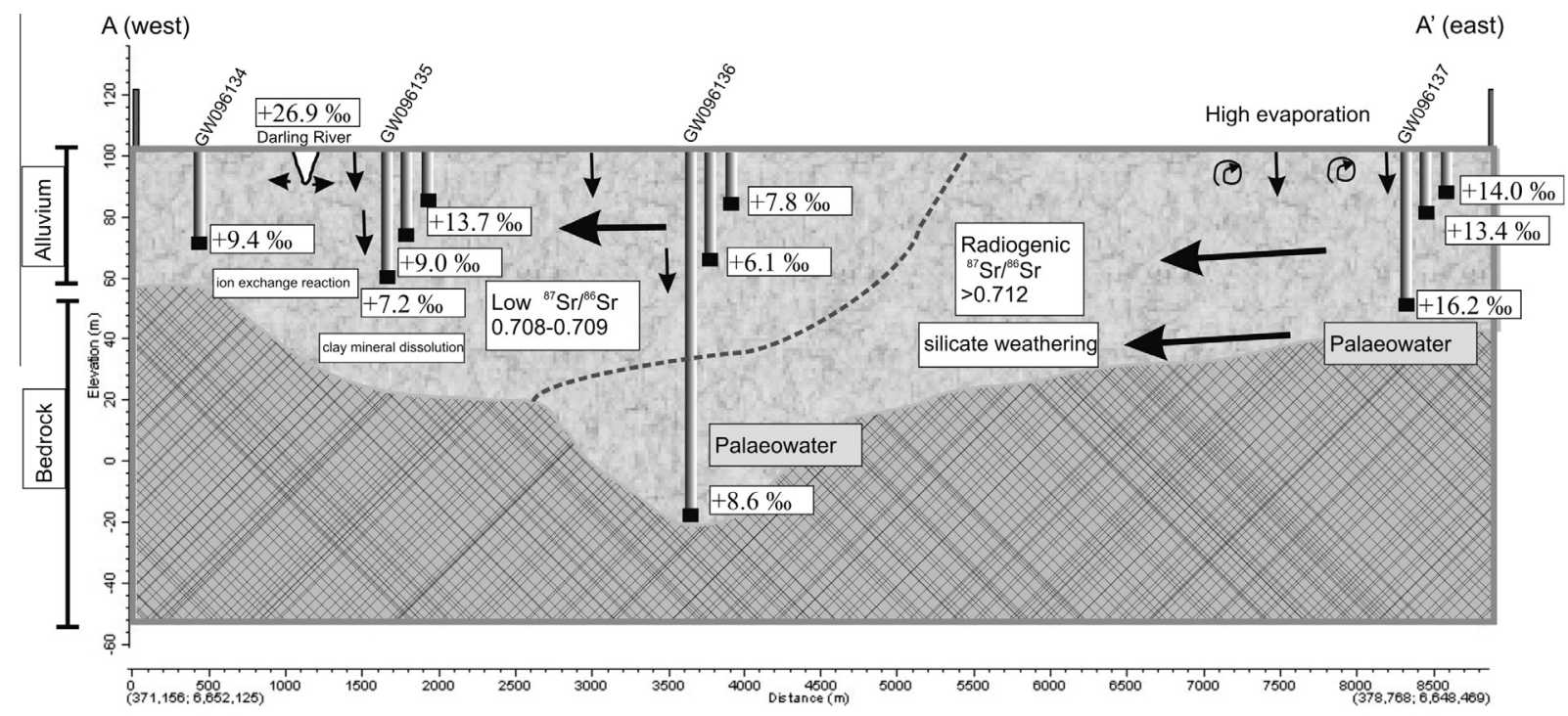

Fig. 7. Hydrogeological cross section dissecting the Darling River showing groundwater flow direction with respect to $\delta^{7} \mathrm{Li}$ values (see Fig. 1 for location of $\mathrm{A}-\mathrm{A}^{\prime}$ ). The extent of weathering and presence of palaeowaters is shown.

to the entire data set for the area (Fig. 6). The similarity in the $\delta^{7} \mathrm{Li}$ values indicate exchange reactions with clay minerals in the alluvium are a consistent source of $\mathrm{Li}$ even if groundwater residence time and/or salinity are different at depth $(>100 \mathrm{~km})$. Deeper wells located closest to the river $(<0.6 \mathrm{~km})$ have lower $\delta^{11} \mathrm{~B}$ values $(+44.7$ to $+47.5 \%)$ and ${ }^{87} \mathrm{Sr} /{ }^{86} \mathrm{Sr}$ signatures between 0.708 and 0.709 . At a greater distance from the river channel $(2.5 \mathrm{~km})$, sample $96136 / 3$ has a higher $\delta^{11} \mathrm{~B}\left(+52.8 \%\right.$ ond more radiogenic ${ }^{87} \mathrm{Sr} /{ }^{86} \mathrm{Sr}$ value $(0.712)$. Varying groundwater residence times, $\delta^{11} \mathrm{~B}$ and ${ }^{87} \mathrm{Sr} /{ }^{86} \mathrm{Sr}$ values reflect the mixing of groundwaters that have undergone different hydrochemical evolutionary pathways. The increase in radiogenic $\mathrm{Sr}$ at $2.5 \mathrm{~km}$ from the river is most likely from silicate weathering reactions which have not dominated the evolution of shallow and deep groundwaters located close to the river (Fig. 7).

\subsubsection{Saline groundwaters located $7 \mathrm{~km}$ from the river}

Groundwaters located approximately $7 \mathrm{~km}$ from the channel at depths from 15 to $52 \mathrm{~m}$ bgs consistently show elemental and isotopic characteristics that are not congruent with the other saline samples. These samples have elevated average $\delta^{7} \mathrm{Li}, \delta^{11} \mathrm{~B}$ and ${ }^{87} \mathrm{Sr} /{ }^{86} \mathrm{Sr}$ values, and form distinctive isotopic highs on most plots (Fig. 4). It appears that the composition of these saline groundwaters are not related to the evolution of the other samples of the area because the low $\mathrm{Li}$ and $\mathrm{Sr}$ concentrations compared to other saline groundwaters suggest they have not progressively evolved from dilute groundwater.

When considered as groundwaters that have evolved from independent sources, the elevated $\delta^{7} \mathrm{Li}$ values $(\sim 8 \%$ o higher than the average values after recharge) observed can be explained by fractionation during weathering. The shallow aquifer located $7 \mathrm{~km}$ from the river does not experience regular river recharge and very little rainfall $\left(<360 \mathrm{~mm} \mathrm{yr}^{-1}\right)$. In a weathering environment where water/sediment ratio is low, such as this, it is ideal condi- tions for ${ }^{7} \mathrm{Li}$ to be mobilised into the groundwater. Pistiner and Henderson (2003) found that fractionation can result from primary weathering and also sorption onto surfaces of secondary minerals. Primary weathering and adsorption processes would also explain the very high $\delta^{11} \mathrm{~B}$ values found in this part of the alluvium.

The shallow samples (15-22 m bgs) have very high B concentrations and the highest $\delta^{11} \mathrm{~B}$ measured values, yet have lower $\mathrm{Li}$ and $\mathrm{Sr}$ concentrations than other saline groundwaters closer to the river $(<2.5 \mathrm{~km})$. Interestingly, shallow groundwaters have $\delta^{11} \mathrm{~B}$ values that are close to some of the highest ever reported (Vengosh et al., 1991a,b, 1994). Boron is a highly soluble element and tends to concentrate where water circulation is limited. The decrease in water/sediment ratio with distance from the river channel would be conducive to $\mathrm{B}$ accumulation and hence fractionation from weathering processes. The presence of radiogenic ${ }^{87} \mathrm{Sr} /{ }^{86} \mathrm{Sr} \quad(>0.712)$ values corroborates the hypothesis that fractionation is from primary weathering i.e. silicate weathering leading to the addition of more radiogenic $\mathrm{Sr}$.

Differences between the shallow (15-22 $\mathrm{m} \mathrm{bgs}$ ) and deeper older $(52 \mathrm{~m} \mathrm{bgs})$ groundwaters at this site are also observed. Through the profile from 22 to $52 \mathrm{mbgs}$ an enrichment in $\delta^{7} \mathrm{Li}(2.8 \%$ oo with no corresponding increase in $\mathrm{Li}$ concentration, and an increase in radiogenic $\mathrm{Sr}$ but with lower $\mathrm{Sr}$ concentrations is observed. The decreases in $\delta^{11} \mathrm{~B}(5.1 \%)$, B concentration and the presence of an extremely old groundwater ( $\sim 36 \mathrm{ka})$ provides further evidence of the difference between shallow and deeper groundwaters. An extremely low recharge rate of $0.1 \mathrm{~mm} \mathrm{yr}^{-1}$ was calculated based on the ${ }^{14} \mathrm{C}$ age, further suggesting piston flow recharge is not responsible for the deeper groundwater and that the shallow system is separated from an underlying much older geochemically mature groundwater system. The dissimilarities in hydrochemistry of the groundwaters from different depths indicate a palaeowater that has evolved 
along a different hydrochemical pathway. Either groundwater originating from outside the study area is flowing towards the river or more likely it is migrating upwards from the bedrock at this site (Fig. 7).

\section{CONCLUSIONS}

This study highlights the importance of using a multiisotopic approach to understanding recharge processes and water-sediment interaction in a salinised groundwater environment. The use of $\delta^{7} \mathrm{Li}, \delta^{11} \mathrm{~B}$ and ${ }^{87} \mathrm{Sr} /{ }^{86} \mathrm{Sr}$ isotopic tracers have been essential in identifying hydrochemical variations along a relatively short, well defined groundwater flow path. Traditional hydrochemical and isotopic tracers in saline groundwaters in the Glen Villa area showed limited variability. But by using trace element isotopes more detailed hydrogeochemical processes such as watersediment reactions and mixing of palaeowaters were identified. The complex isotopic systematics have been interpreted by examining the groundwaters as subsets of samples from different depths and/or distances from the river. The end-members included: shallow dilute waters from wells proximal to the channel, saline groundwaters from wells located the furthest distance from the channel, and deep saline groundwaters.

By interpreting the data in this manner, it was found that simple groundwater mixing models could not explain all the variation observed in this groundwater system and the Glen Villa groundwater system is not an example of large-scale simple mixing between fresh river water and a saline groundwater end-member. It was found that after groundwater recharge, little of the original $\mathrm{Li}$ isotopic character of the river water was retained after even short-term interaction with sediments in the subsurface. The groundwaters influenced by river recharge are controlled by water-sediment reactions that varied substantially within the unsaturated zone. Groundwater-surface water exchange from fresh bank storage forms dilute groundwaters where $\mathrm{Li}, \mathrm{B}$ and $\mathrm{Sr}$ are contributed from clay mineral reactions. The majority of the saline samples close to the river $(<2.5 \mathrm{~km})$ had $\delta^{7} \mathrm{Li}, \delta^{11} \mathrm{~B}$ and ${ }^{87} \mathrm{Sr} /{ }^{86} \mathrm{Sr}$ values intermediate between the shallow dilute and deep saline groundwaters, suggesting the mixing of these quasi-end-member groundwaters would produce the observed groundwater chemistry. Further supporting the hydrological interpretation that groundwaters near the river channel originated from the Darling River. The deepest saline groundwaters were found to be old $(>5 \mathrm{ka})$ and had well constrained $\delta^{7} \mathrm{Li}$ values. However, varied $\delta^{11} \mathrm{~B}$ and ${ }^{87} \mathrm{Sr} /{ }^{86} \mathrm{Sr}$ signatures for the deep waters located $2.5 \mathrm{~km}$ from the river highlighted the different sources of waters at depth.

Groundwaters located approximately $7 \mathrm{~km}$ from the channel formed distinctive isotopic highs and were found not to be related to the evolution of the other samples of the area. The elevated $\delta^{7} \mathrm{Li}$ and $\delta^{11} \mathrm{~B}$ observed can be explained by fractionation from prolonged primary weathering and radiogenic ${ }^{87} \mathrm{Sr} /{ }^{86} \mathrm{Sr}$ values corroborate this process. A deeper isolated older groundwater system was also identified. Trace element isotopes have also provided further information on the groundwater flow paths of this understudied aquifer. This study highlights the importance of a multi-tracer approach, including the use of trace element isotopes, in resolving complex geochemical processes in groundwater in semi-arid to arid zone environments.

\section{ACKNOWLEDGEMENTS}

The authors would like to thank various ANSTO personnel for their help in the field and laboratories. Thank you to Dr. Mathew Johansson for his review of the manuscript. We would also like to thank the Department of Water and Energy, NSW, Australia for providing collaborative support on this project with special mention to Mike Williams, Hari Haridharan and Jim McCartney.

\section{REFERENCES}

Barth S. R. (2000) Geochemical and boron, oxygen and hydrogen isotopic constraints on the origin of salinity in groundwaters from the crystalline basement of the Alpine Foreland. Appl. Geochem. 15, 937-952.

Bottomley D. J., Katz A., Chan L. H., Starinsky A., Douglas M., Clark I. D. and Raven K. G. (1999) The origin and evolution of Canadian Shield brines: evaporation or freezing of seawater? New lithium isotope and geochemical evidence from the Slave craton. Chem. Geol. 155, 295-320.

Burke W. H., Denison R. E., Hetherington E. A., Koepnick R. B., Nelson H. F. and Otto J. B. (1982) Variation of seawater ${ }^{87} \mathrm{Sr} /{ }^{86} \mathrm{Sr}$ throughout Phanerozoic time. Geology 10, 516-519.

Chan L. H., Starinsky A. and Katz A. (2002) The behaviour of lithium and its isotopes in oilfield brines: evidence from the Heletz-Kokhav field, Israel. Geochim. Cosmochim. Acta 66, 615-623.

Chaussidon M. and Albarede F. (1992) Secular boron isotope variations in the continental crust: an ion microprobe study. Earth Planet. Sci. Lett. 108, 229-241.

d' Hautefeuille F., Williams R. (2003) Upper Darling Salt Interception Scheme - Preliminary investigation to May 2003. In NSW Department of Infrastructure (Editor). Centre for Natural Resources NSW Department of Infrastructure, Planning and Natural Resources Parramatta. ISBN: 0-7347-5421-3.

Douglas G. B., Hart B. T., Beckett R., Gray C. M. and Oliver R. (1999) Geochemistry of suspended particulate matter (SPM) in the Murray-Darling River system: a conceptual isotopic/ geochemical model for the fractionation of major, trace and rare earth elements. Aquat. Geochem. 5, 167-194.

Hogan J. F. and Blum J. D. (2003) Boron and lithium isotopes as groundwater tracers: a study at the Fresh Kills Landfill, Staten Island, New York, USA. Appl. Geochem. 18, 615-627.

Huh Y., Chan L. H., Zhang L. and Edmond J. M. (1998) Lithium and its isotopes in major world rivers: implications for weathering and the oceanic budget. Geochim. Cosmochim. Acta 62, 2039-2051.

Kisakurek B., James R. H. and Harris N. B. W. (2005) Li and $\delta^{7} \mathrm{Li}$ in Himalayan Rivers: proxies for silicate weathering? Earth Planet. Sci. Lett. 237, 387-401.

Kloppmann W., Van Houtte E., Picot G., Vandenbohede A., Lebbe L., Guerrot C., Millot R., Gaus I. and Wintgens T. (2008a) Monitoring reverse osmosis treated wastewater recharge into a coastal aquifer by environmental isotopes (B, Li, O, H). Environ. Sci. Technol. 42, 8759-8765.

Kloppmann W., Vengosh A., Guerrot C., Millot R. and Pankratov I. (2008b) Isotope and ion selectivity in reverse osmosis desalination: geochemical tracers for man-made freshwater. Environ. Sci. Technol. 42, 4723-4731. 
Kloppmann W., Chikurel H., Picot G., Guttman J., Pettenati M., Aharoni A., Guerrot C., Millot R., Gaus I. and Wintgens T. (2009) $\mathrm{B}$ and $\mathrm{Li}$ isotopes as intrinsic tracers for injection tests in aquifer storage and recovery systems. Appl. Geochem. 24, 1214 1223.

Lemarchand E., Schott J. and Gaillardet J. (2005) Boron isotopic fractionation related to boron sorption on humic acid and structure of surface complexes formed. Geochim. Cosmochim. Acta 69, 3519-3533.

Lemarchand D. and Gaillardet J. (2006) Transient features of the erosion of shales in the Mackenzie basin (Canada), evidence from boron isotopes. Earth Planet. Sci. Lett. 245, 174-189.

Lemarchand E., Chabaux F., Vigier N., Millot R. and Pierret M. C. (2010) Lithium isotope systematics in a forested granitic catchment (Strengbach, Vosges Mountains, France). Geochim. Cosmochim. Acta 74, 4612-4628.

$\mathrm{Lu}$ Y., Makishima A. and Nakamura E. (2007) Coprecipitation of $\mathrm{Ti}, \mathrm{Mo}, \mathrm{Sn}$ and $\mathrm{Sb}$ with fluorides and application to determination of $\mathrm{B}, \mathrm{Ti}, \mathrm{Zr}, \mathrm{Nb}, \mathrm{Mo}, \mathrm{Sn}, \mathrm{Sb}$, Hf and Ta by ICP-MS. Chem. Geol. 236, 13-26.

Meredith K. T., Hollins S. E., Hughes C. E., Cendón D. I., Hankin S. and Stone D. J. M. (2009) Temporal variation in stable isotopes $(18 \mathrm{O}$ and $2 \mathrm{H})$ and major ion concentrations within the Darling River between Bourke and Wilcannia due to variable flows, saline groundwater influx and evaporation. J. Hydrol. 378, 313-324.

Meredith K., Cendón D. I., Pigois J.-P., Hollins S. and Jacobsen G. (2012) Using ${ }^{14} \mathrm{C}$ and ${ }^{3} \mathrm{H}$ to delineate a recharge 'window' into the Perth Basin aquifers, North Gnangara groundwater system, Western Australia. Sci. Total Environ. 414, 456-469.

Millot R., Négrel P. and Petelet-Giraud E. (2007) Multi-isotopic $(\mathrm{Li}, \mathrm{B}, \mathrm{Sr}, \mathrm{Nd})$ approach for geothermal reservoir characterization in the Limagne Basin (Massif Central, France). Appl. Geochem. 22, 2307-2325.

Millot R. and Négrel P. (2007) Multi-isotopic tracing $\left(\delta^{7} \mathrm{Li}, \delta^{11} \mathrm{~B}\right.$, ${ }^{87} \mathrm{Sr} /{ }^{86} \mathrm{Sr}$ ) and chemical geothermometry: evidence from hydrogeothermal systems in France. Chem. Geol. 244, 664-678.

Millot R., Vigier N. and Gaillardet J. (2010) Behaviour of lithium and its isotopes during weathering in the Mackenzie Basin, Canada. Geochimica et Cosmochimica Acta 74, 3897-3912.

Moriguti T. and Nakamura E. (1998a) Across-arc variation of Li isotopes in lavas and implications for crust/mantle recycling at subduction zones. Earth Planet. Sci. Lett. 111, 331-349.

Moriguti T. and Nakamura E. (1998b) High-yield lithium separation and the precise isotopic analysis for natural rock and aqueous samples. Chem. Geol. 145, 91-104.

Moriguti T., Shibata T. and Nakamura E. (2004a) Lithium, boron and lead isotope and trace element systematics of Quaternary basaltic volcanic rocks in northern Japan: mineralogical controls on slab-derived fluid composition. Chem. Geol. 212, 81100.

Moriguti T., Makishima A. and Nakamura E. (2004b) Determination of lithium contents in silicates by isotope dilution ICPMS and its evaluation by isotope dilution thermal ionisation mass spectrometry. Geostand. Geoanal. Res. 28, 371-382.

Nakamura E., Ishikawa T., Birck J.-L. and Allègre C. J. (1992) Precise boron isotopic analysis of natural rock samples using a boron-mannitol complex. Chem. Geol. 94, 193-204.

Nakamura E., Makishima A., Moriguti T., Kobayashi K., Sakaguchi C., Yokoyma T., Tanaka R., Kuritani T., Takei H. (2003) Comprehensive geochemical analyses of small amounts $(<100$ $\mathrm{mg}$ ) of extraterrestrial samples for the analytical competition related to the sample return mission MUSES-C. In Inst. Space and Astron. Sci. Report. SP No. 16 (eds. I. Kushiro, A. Fujiwara and H. Yano; Asteroidal Sample Preliminary Examination Team). Sagamihara, Japan. pp. 49-101.
Nakano T. and Nakamura E. (1998) Static multicollection of $\mathrm{Cs}_{2} \mathrm{BO}_{2}{ }^{+}$ions for precise boron isotope analysis with positive thermal ionization mass spectrometry. Int. J. Mass Spectrom. 176, 13-21.

Négrel P., Millot R., Brenot A. and Bertin C. (2010) Lithium isotopes as tracers of groundwater circulation in a peat land. Chem. Geol. 276, 119-127.

Palmer M. R., Spivack A. J. and Edmond J. M. (1987) Temperature and $\mathrm{pH}$ controls over isotopic fractionation during adsorption of boron on marine clay. Geochim. Cosmochim. Acta 51, 2319-2323.

Pistiner J. S. and Henderson G. M. (2003) Lithium-isotope fractionation during continental weathering processes. Earth Planet. Sci. Lett. 214, 327-339.

Pogge von Strandmann P. A. E., Burton K. W., James R. H., van Calsteren P., Gíslason S. R. and Mokadem F. (2006) Riverine behaviour of uranium and lithium isotopes in an actively glaciated basaltic terrain. Earth Planet. Sci. Lett. 251, 134-147.

Rose E. F., Chaussidon M. and France-Lanord C. (2000) Fractionation of Boron isotopes during erosion processes: the example of Himalayan rivers. Geochim. Cosmochim. Acta 64, 397-408.

Schwarcz H. P., Agyei E. K. and McMullen C. C. (1969) Boron isotopic fractionation during clay adsorption from sea-water. Earth Planet. Sci. Lett. 6, 1-5.

Spivack A. J. and Edmond J. M. (1987) Boron isotope exchange between seawater and the oceanic crust. Geochim. Cosmochim. Acta 51, 1033-1043.

Tamers M. A. (1975) Validity of radiocarbon dates on ground water. Geophys. Surv. 2, 217-239.

Tang Y. J., Zhang H.-F., Nakamura E., Moriguti T., Kobayashi K. and Ying J.-F. (2007) Lithium isotopic systematics of peridotite xenoliths from Hannuoba, North China Craton: implications for melt-rock interaction in the considerably thinned lithospheric mantle. Geochim. Cosmochim. Acta 71, 4327-4341.

Teng F. Z., McDonough W. F., Rudnick R. L., Dalpé C., Tomascak P. B., Chappell B. W. and Gao S. (2004) Lithium isotopic composition and concentration of the upper continental crust. Geochim. Cosmochim. Acta 68, 4167-4178.

Tomascak P. B., Carlson R. W. and Shirey S. B. (1999) Accurate and precise determination of $\mathrm{Li}$ isotopic compositions by multicollector sector ICP-MS. Chem. Geol. 158, 145-154.

Tomascak P. B., Hemming N. G. and Hemming S. R. (2003) The lithium isotopic composition of waters of the Mono Basin, California. Geochim. Cosmochim. Acta 67, 601-611.

Vengosh A., Chivas A. R., McCulloch M. T., Starinsky A. and Kolodny Y. (1991a) Boron isotope geochemistry of Australian salt lakes. Geochim. Cosmochim. Acta 55, 2591-2606.

Vengosh A., Starinsky A., Kolodny Y. and Chivas A. R. (1991b) Boron isotope geochemistry as a tracer for the evolution of brines and associated hot springs from the Dead Sea, Israel. Geochim. Cosmochim. Acta 55, 1689-1695.

Vengosh A., Heumann K. G., Juraske S. and Kasher R. (1994) Boron isotope application for tracing sources of contamination in groundwater. Environ. Sci. Technol. 28, 1968-1974.

Yoshikawa M. and Nakamura E. (1993) Precise isotope determination of trace amounts of $\mathrm{Sr}$ in magnesium-rich samples. Jpn. J. Min. Pet. Econ. Geol. 88, 548-561.

You C. F., Gieskes J. M., Lee T., Yui T. F. and Chen H. W. (2004) Geochemistry of mud volcano fluids in the Taiwan accretionary prism. Appl. Geochem. 19, 695-707. 